\title{
Mergers and alliances in the multimedia market
}

\author{
Citation for published version (APA):
}

van Wegberg, M. J. (1995). Mergers and alliances in the multimedia market. METEOR, Maastricht University School of Business and Economics. METEOR Research Memorandum No. 007 https://doi.org/10.26481/umamet.1995007

Document status and date:

Published: 01/01/1995

DOI:

10.26481/umamet.1995007

Document Version:

Publisher's PDF, also known as Version of record

\section{Please check the document version of this publication:}

- A submitted manuscript is the version of the article upon submission and before peer-review. There can be important differences between the submitted version and the official published version of record.

People interested in the research are advised to contact the author for the final version of the publication, or visit the DOI to the publisher's website.

- The final author version and the galley proof are versions of the publication after peer review.

- The final published version features the final layout of the paper including the volume, issue and page numbers.

Link to publication

\footnotetext{
General rights rights.

- You may freely distribute the URL identifying the publication in the public portal. please follow below link for the End User Agreement:

www.umlib.nl/taverne-license

Take down policy

If you believe that this document breaches copyright please contact us at:

repository@maastrichtuniversity.nl

providing details and we will investigate your claim.
}

Copyright and moral rights for the publications made accessible in the public portal are retained by the authors and/or other copyright owners and it is a condition of accessing publications that users recognise and abide by the legal requirements associated with these

- Users may download and print one copy of any publication from the public portal for the purpose of private study or research.

- You may not further distribute the material or use it for any profit-making activity or commercial gain

If the publication is distributed under the terms of Article $25 \mathrm{fa}$ of the Dutch Copyright Act, indicated by the "Taverne" license above, 
M. van Wegberg ${ }^{1}$

In the multimedia market, mergers and alliances are alternative ways to coordinate decision making about, especially, technology policies. Salient characteristics of multimedia explain why the amount of mergers and alliances rose during the 1990s. They may also effect the choice by firms among coordination forms, e.g., between merger and an alliance. The paper points to the implications of convergence, shorter product life cycles, and standardization.

JEL Code (new series): L82

1. Rijksuniversiteit Limburg, P.O. Box 616, 6200 MD Maastricht, The Netherlands, tel. +31 43 883654, fax +31 43 258495, e-mail: M.vanWegberg@MW.RuLimburg.nl. The research was partly financed by a grant from the Dutch science foundation NWO. 


\section{Introduction}

Multimedia began as a market in 1991, when the Commodore CDTV, Philips's CD-i and the Windows Multimedia PC were introduced. Developments, however, started as early as 1986, when Philips and Sony introduced CD-ROM, and several companies began to prepare multimedia machines. Multimedia exists at the intersection of several information technology industries (IT for short). Companies in several IT markets attempt entry into the multimedia market, and multimedia plays a pivotal role in the strategies of these firms. Most firms believe they can not develop a multimedia strategy on their own accord: they need to collaborate. This has inspired many mergers and alliances. According to Business Week (12-7-93, p. 96), Trade newsletter Digital Media has counted up no fewer than 348 alliances in pursuit of multimedia services.' In the U.S., 1993 and 1994 showed an upsurge of merger activity comparable to 1988 and 1989 (The Economist, 10-9-1994, p. 90). The media and telecom markets made a large contribution to this wave, witnessing Viacom's \$10b acquisition of Paramount in 1994 and AT\&T's acquisition of McCaw Cellular in 1993. In 1995, Microsoft is involved in taking over Intuit, a firm whose software aims

at home users. The emergence of multimedia is one of the reasons given for many of these mergers and acquisitions.

The content of the paper is as follows. The second section discusses motives for mergers and alliances, according to theoretical and empirical papers. The third section discusses several trends around multimedia, such as convergence, shorter product life cycles, and standardization. The next section contains four cases of innovations and strategies in multimedia. They show the effects of innovations on mergers and alliances, and the importance of managing and coordinating mergers and alliances. The appraisal suggests which arguments induce firms to cooperate either through a merger or through an alliance.

\section{Mergers and alliances}

Mergers and alliances are both instruments in coordinating the strategies of firms. There are several reasons for wanting better coordination. Industry standards (if not imposed by the government) emerge only if firms can (be forced to) agree on them. Many decisions create interdependencies between firms. In the case of process innovations, for example, R\&D affects production costs, and costs in turn affect competition in the product market. Know how may leak to other firms, in other words, R\&D may have positive spillovers on other firms. This provides firms with an additional motive to coordinate their R\&D decisions: to internalize these externalities.

Table 1 gives some pros and cons of merger and alliance. Mergers and alliances are both instruments in improving one's competitiveness (market positioning). An alliance allows firms to share costs, and to pool risks. It also allows firms to specialise, to the benefit of the overall quality of the joint project. A firm can enter into numerous alliances (thus creating a network), while it can acquire only so many firms. An alliance usually has an objective which is focused and specified ex ante. It may, for example, entail a project with given time schedule, budget, and partners' contributions. A merger or acquisition instead allows firms to coordinate a wide variety of 


\begin{tabular}{||l|l|l||}
\hline \hline Strengths & Merger/ acquisition & Alliance \\
& $\begin{array}{l}\text { Commitment } \\
\text { Conflict resolution by authority } \\
\text { Preemption of acquisition target's } \\
\text { resources } \\
\text { Market power (in input and output } \\
\text { markets) }\end{array}$ & $\begin{array}{l}\text { Specialisation } \\
\text { Focus on clear objective } \\
\text { Participation in several alliances possible } \\
\text { Sharing costs and risks } \\
\text { Discretion of management (financial } \\
\text { markets not involved) }\end{array}$ \\
\hline Weaknes & $\begin{array}{l}\text { Organizational issues (integration, } \\
\text { size, mismatch of activities) } \\
\text { Transaction costs in financial } \\
\text { markets } \\
\text { Antitrust }\end{array}$ & $\begin{array}{l}\text { Opportunism (hidden agendas) } \\
\text { Leaks of know how } \\
\text { Fragile (m any breakups) } \\
\text { Partners are potential rivals } \\
\text { Asymmetric distribution of costs and } \\
\text { revenues among partners }\end{array}$ \\
\hline
\end{tabular}

Table 1

decisions, without specifying them ex ante. A merger allows for tighter coordination and provides more commitment to project or technology. Mergers are more costly to realise than alliances, as a merger or takeover may have far going implications for shareholders and the equity markets. This suggests that a large firm has better access to this instrument than a small firm. Thus large firms may be more 'acquisition-active' than smaller firms. A firm may want to own its core resources (competencies). A merger is the preferred route when the participants seek synergy among their core resources (Hart and Moore, 1990, p. 1135). This suggests that an alliance will coordinate decisions and combine resources that are adjacent to a firm's core competencies. If firms face the choice among incompatible standards and if they cannot merge (for example, for legal reasons), they may prefer a standard-setting committee to independent choice of a standard (Farrell and Saloner, 1988). I will next consider some empirical and theoretical evidence.

\subsection{Empirical results}

Chakrabarti, Hauschildt and Süverkrüp (1994) conclude from the literature that technology ranks in the middle of the strategic considerations of acquisitions (behind motives such as market dominance, market shares, and cost reduction). In a sample of 86 German-American foreign acquisitions in 1978-1987, they distinguish the acquirers in four groups on the basis of their motives: market-oriented entrepreneurs, short-term profit seekers, technology acquirers and preemptive market protectors. The latter two are interested in technology transfers, and are mainly located in high-tech industries. Technology plays a large part in some but not all mergers, therefore. The same holds for alliances. For example, in a Belgian database of alliances, research and development appeared the motive (or functional activity) for $20.9 \%$ of the non-Belgian alliances, and $25.3 \%$ for the Belgian alliances (i.e., alliances which include at least one Belgian firm) (Veugelers, 1993, p. 7).

In these cases, mergers and alliances are substitute sources of technology coordination. This is confirmed by Link and Bauer (1989), who found that (according to the managers involved) 
mergers and alliances were (on average) less important sources of technology than own R\&D but more important than licensing. Comparing the managers' views in 1982 to the ones in 1985, they also found that mergers decreased in importance as a source of technology, whereas cooperative research increased in importance.

\subsection{Some theoretical insights}

Theoretical research in industrial economics explores how salient aspects of mergers and alliances affect the firms' choice and the performance effects of mergers and alliances. Industrial economists stress one aspect in particular. An alliance is topical: it coordinates a particular objective or project. A merger or acquisition, instead, allows the firms to coordinate all decisions, from pre-competitive decisions about $R \& D$ to product market decisions. D'Aspremont and Jacquemin (1988) and De Bondt and Veugelers (1991) analyze the implications of this in the following setting. Two firms compete in the product market as Cournot duopolists (with heterogeneous products). They also do R\&D, which reduces their marginal costs (process innovation), and thus affects their subsequent decisions about output levels. Each firm's R\&D leaks somewhat to its rival. That is, it has a positive spillover on the other firm's know how, and thus reduces its marginal cost level as well. Both firms may compete both in R\&D and, subsequently, in output levels. If they form an $R \& D$ alliance, they coordinate their $R \& D$ decisions, while competing in the product market. If they merge, they coordinate both their R\&D and output decisions. D'Aspremont and Jacquemin (1988) and De Bondt and Veugelers (1991) show that the greater degree of coordination achieved by the merger means that it is more profitable than an alliance. This result is too straightforward. Refinements of these seminal papers offer more clues about firms' choices and effects of mergers and alliances.

\subsubsection{Rivals and convergence}

Introduce in their setting a third (non-innovating and non-merging) firm (Van Wegberg, 1994b). This firm represents 'competition' to the two cooperating firms. If they merge, for example, the market becomes a duopoly with the third firm, rather than a monopoly, as in the seminal papers mentioned above. The introduction of competition now implies that a merger is no longer necessarily more profitable than an alliance. Profitability depends on whether the products of the three firms are substitutes or complements. The main result is that firms organise joint R\&D by merging if their products are complements or imperfect substitutes, and by forging an alliance if their products are close substitutes. Although the multimedia industry shows many examples that fit this description, it also features mergers among close rivals, and alliances among suppliers of complements (e.g., hardware and software). A process of convergence that leads to products becoming better substitutes would lead to an increasing number of alliances relative to the number of mergers or acquisitions.

\subsubsection{Cartels and the product life cycle}

A merger or alliance may serve a covert aim besides the overt one of coordinating technology policies. Firms may try to form a tacit cartel. A merger, for example, raises market concentration, which may facilitate tacit collusion or cartel formation in a market. Davidson and Deneckere 
(1984) show that the opposite may hold: a merger may disrupts collusion. What keeps collusion going among rivals, is the threat that if one firm exploits its rivals' collusion by secret price cutting, others will retaliate by reverting to competition. The effect of a merger is that it raises the profits in competition (by creating market power), thus reducing the threat value of a reversal to competition. The latter effect weakens the cartel, and may even destroy it. If fims anticipate this, they face the choice between either merger (and thus competition, among a reduced number of firms) or collusion (by a larger number of firms). Unlike a merger, an alliance does not increase market power in the product market. By not raising the profit margins in competition, it may ironically support collusion (Van Wegberg, 1995a). For this reason, R\&D alliances may be consistent with tacit cartels in situations where a merger might disrupt the cartel. It holds that if products become better substitutes, this destroys the possibilities for collusion. Shorter product life cycles may in some cases induce a switch from an alliance to merger, such that collusion breaks down.

\subsubsection{R\&D specialists and manufacturers}

In high tech markets, one often observes a merger or alliance between an R\&D firm and manufacturing firm(s). Since these vertically related firms do not compete with each other, the merger does not intend to create market power. Van Wegberg (1995b) has a model along the lines set out above. The product market is a duopoly of two non-innovating manufacturing firms. The innovator may merge with one manufacturer or form an alliance with both. ${ }^{2}$ An alliance leads to a lower R\&D investment than a merger, lower aggregate profits, but also to a higher output level, and thus a lower market price. Alternatively, the researcher may license its technology to the two manufacturing firms (a market contract, rather than a merger or alliance). The alliance is less profitable than both the merger and the market contract. If scope for technological progress is small (i.e., R\&D is costly), the firms collectively benefit from the market contract; otherwise the merger is more profitable. Thus increasing technological fertility induces a switch from market contracts to mergers, which seems a meaningful result.

\section{Developments in multimedia}

Several trends exist in the multimedia market that may affect activities in mergers and alliances.

\subsection{Convergence}

Since the mid-1980s observers speak of the convergence of the information technology industries. IT represents several markets of computers, consumer electronics, telecommunications, and (multi)media. On the supply side, convergence means that these industries increasingly use the same knowledge base. Digitization is the ubiquitous trend. Increasingly, the same technologies for storing, (de)compressing, transmitting, and processing digital data are used throughout the IT industries. On the demand side, convergence means that market boundaries become fuzzier, both

2. An alliance of the innovator with one manufacturer would, in the model, have the same results as a merger with that firm. 
within the IT industries and between them. On the one hand, some previously unrelated products become substitutes in demand. Examples are computers: see the substitution from mainframes, mini computers, and computer workstations to PCs. Others are the computer operating systems, telephone lines and cable (substitutes for interactive television), fax machines and computers (where the latter have fax software plus a modem), and television and computers (substitutes for interactive CDs and for on-line services. On the other hand, some products become complements. This applies to telephones and computers, once they are linked by a modem for e-mail and other on-line services. Since many IT products experience that they face closer substitutes, coordination among their suppliers would take the form of alliances rather than mergers (Van Wegberg, 1994b).

\subsection{Waves of innovations}

New technologies in multimedia have several effects. Miniaturisation being an ongoing trend, multimedia may become increasingly ubiquitous. Portable computers, Personal Digital Assistants (PDAs), and interactive telephones or Smartphones, will increasingly embrace interactive, multimedia characteristics. Product innovations that utilize the miniaturisation trend will, therefore, continue to make the market expand.

Multimedia displays a high market volatility or market fluidity (De Jong, 1993). Innovations help newcomers to leapfrog established players. At all levels of the market (operating systems, hardware, and software) waves of entry occur. Since multimedia exists at the intersection of amusement, computers, consumer electronics, and telecom, it is invaded from all these directions. Newcomers are either established players in these markets, really new firms, or offsprings of established players (with their financial support, or created by their ex-employees). The market is volatile, market shares are still vulnerable, and no dominant firms have yet settled themselves. The demand side also accounts for market volatility. Children play a large part in buying decisions of multimedia machines (Adformatie, 26-1-95, p. 35). And children are given to fads, which tends to make a market volatile.

In an increasingly rapid succession of innovations, each innovation tends to reduce the product life of previous innovations. Throughout the computer industry one observes that the product life cycles are getting shorter, down to six months. In multimedia, newness and specs are salient selling points. Sony's PlayStation and Sega's Saturn were quick to draw attention away from 3DO, which in turn had tried to turn the tables on CD-i. Atari, in turn, has leapfrogged all with the world's first 64 bit machine, the Jaguar, which is hampered, however, by lack of software support. A process of shortening product life cycles tends to nip emerging cartels in the bud, and tends to favour mergers over alliances (V an Wegberg, 1995a).

\subsection{Introducing standards}

The success of a firm's innovations depends on its quality to consumers. For an information product, quality depends on more than technical specifications. It needs the widest possible access to information sources (which themselves are stored on CDs or accessible on-line). An innovation in information technology requires standards that govern how it stores, retrieves, (de)compresses, processes, and transmits information. An operating system defines an architecture consisting of 
numerous standards, for each type of information and processing (Ferguson and Morris, 1994). A fully fledged multimedia architecture currently should be able to playback a Video CD movie, a disc with photos in the PhotoCD standard, and, of course, audio CDs. To establish a standard requires that it receives the widest possible support from consumers, suppliers of hardware and software. To successfully introduce a standard, one needs early entry (before rival standards emerge), large size (to establish the standard in many markets), and the ability to create alliances with important decision makers. This insight lurks behind many mergers and alliances.

\subsection{Creating teams of resources and product bundles}

Apart from standard setting, a merger or alliance can also be motivated by the need to create bundles of complementary resources. Multimedia hardware is a combination of operating software, microprocessor, additional chips, CD player, and accessories. The consumers requires both the hardware and software. Writing software for a specific operating system requires authoring tools that tend to be specific to an operating system. Firms in multimedia thus need to introduce a system consisting of numerous components. No firm seems able to combine internally all assets required to achieve this on its own. It either needs to acquire firms with complementary assets, or it needs to form alliances, or both. The objective of a merger or acquisition is, therefore, to create market power (in input or output markets), to coordinate decision making (for efficiency reasons), raise the firm's power to establish a standard, or to combine complementary resources. An alliance may serve these objectives as well, with a focus on the latter two objectives. These trends form the setting in which firms develop their merger and alliance policies. The next section illustrates this in four case studies.

\section{Cases of Innovations and Strategies in Multimedia}

The following subsections discuss some case studies in multimedia. These highlight the considerations that affect firms' choices between mergers and alliances as alternative modes of cooperation and coordination. An architecture defines the standards that tie the components of a multimedia system together. These components include the operating system, the storage system (a $\mathrm{CD}$, usually), communication protocols, and software. This section discusses all components. Additionally,m it also discusses a major participating firm, Sony.

\subsection{A multimedia architecture}

Numerous multimedia architectures battle it out with one another. This is the clearest indicator of the early stage of multimedia. Some architectures are supported by an alliance of several players. Others are supported by a single player, which has alliances to ensure that all components of the system are supplied. Table 2 lists some standards, their sponsors (a supporting firm or alliance), and the relationship to suppliers of additional components. Alliance policies range from almost non-existent (Commodore) to elaborate (3DO). There is no consensus between the architectural rivals to what extent alliances are required to make one's architecture successful. As yet, no architectural company has been acquired by another firm. Nor does an architectural company seem 


\begin{tabular}{|c|c|c|c|}
\hline Architecture & Owner & $\begin{array}{l}\text { Supplied } \\
\text { by owner }\end{array}$ & Alliances \\
\hline 3DO & 3DO & OS & $\begin{array}{l}\text { OS (3DO alliance of Matsushita, AT\&T, Time } \\
\text { Warner, Electronic Arts) } \\
\text { Hardware (Panasonic; Goldstar) } \\
\text { Software (a.o. Electronic Arts) }\end{array}$ \\
\hline CD-i & Philips & OS, H, S & Philips/Motorola (chips) \\
\hline CD32 & $\begin{array}{l}\text { Commodor } \\
\text { e }\end{array}$ & $\mathrm{OS}, \mathrm{H}$ & \\
\hline Jaguar & Atari & $\mathrm{OS}, \mathrm{H}$ & Atari/IBM \\
\hline $\begin{array}{l}\text { Macintosh + } \\
\text { CD-ROM }\end{array}$ & Apple & $\mathrm{OS}, \mathrm{H}$ & $\begin{array}{l}\text { Apple/IBM/Motorola (Microprocessor) } \\
\text { Apple/IBM (Kaleida: multimedia technology) }\end{array}$ \\
\hline $\begin{array}{l}\text { Multimedia } \\
\text { PC }\end{array}$ & Microsoft & OS,S & $\begin{array}{l}\text { Multimedia PC Marketing Council (OS; AT\&T } \\
\text { Computer Systems, CompuAdd, Creative Labs Inc., } \\
\text { Media Vision, NEC Technologies, Olivetti, Philips, } \\
\text { Tandy, Video Seven, Zenith Data Systems, } \\
\text { Microsoft) }\end{array}$ \\
\hline PlayStation & Sony & OS,H,S & \\
\hline Powerplayer & Apple & OS & Apple/Bandai (H in Japan) \\
\hline Mega CD & Sega & $\mathrm{OS}, \mathrm{H}, \mathrm{S}$ & \\
\hline VIS & Tandy & $\mathrm{H}$ & Tandy/Microsoft (OS) \\
\hline Ultra64 & Nintendo & $\mathrm{OS}, \mathrm{H}, \mathrm{S}$ & Nintendo/ Silicon Graphics (chips) \\
\hline
\end{tabular}

Table 2

to have acquired a supplier of a component of its system. Alliances are, therefore, preferred to merger as the route to supporting an architecture.

\subsection{The high capacity CD format: HDCD versus DVD}

The $\mathrm{CD}$ is the basis to the multimedia market. The storage capacity of the $\mathrm{CD}$ is $650 \mathrm{Mb}$. Although large enough for storing texts, it does impose bottlenecks on storing movies, images and sound. Both the Video CD standard for storing movies and the quality of today's multimedia encyclopedias show the compromises firms have to make to store their material on one CD. The solution to the problem is to raise the storage capacity of the CD. Two standards now battle it out with each other. The Philips/Sony High Density CD (HDCD) has a capacity of 3.7 gigabytes. It allows for 135 minutes of film. A cooperation with $3 \mathrm{M}$ will upgrade the system to 7.4 gigabyte. The alliance is supported by IBM, Apple, Compaq and Microsoft (Volkskrant, 24-1-95). Toshiba and Pioneer have an alternative, called Super Density Disc (DSD). This provides 4.8 gigabyte, on one side of the CD. If double-sided, this would become ten gigabyte. It will be used for Digital 
Video Disc (DVD), which uses MPEG2 to code movies, and offers 180 minutes. The first Digital Video Disc players are expected next year. This alliance is supported by Time Warner, Matsushita, and Thomson Consumer Electronics (Volkskrant, 24-1-95), Hitachi (The Economist, 28-1-95, p. 68), MCA and MGM/UA (Business Week, 20-2-95, p. 44). Toshiba owns a large stake in Time Warner entertainment, and Matsushita owns MCA.

The articles quoted suggest that the latter alliance has the stronger industry support. It is backed by Matsushita, the world's largest consumer electronics company. Matsushita's support helped VHS to victory in the battle with the videocassette standards from Sony (Betamax) and Philips (Video 2000). It is also backed by 'Hollywood'. Business Week (20-2-95, p. 44-46) compares the skilful networking approach of Toshiba/Time Warner favourably to Philips and Sony. The former courted Hollywood aggressively, whereas the latter presented Hollywood with finished specs, instead of seeking advice. The former pushed technology to the limit (ten gigabyte), the latter sacrifice some capacity (7.4 gigabytes) to compatibility with current CD-ROMs. This battle seems to indicate, therefore, the importance of building a large, well-connected network of alliances with important players, of size, and of leapfrogging.

\subsection{Interactive television and the set-top box}

Multimedia products are now stand-alone products. A new development is interactive television, that enhances the television with two-way communication for on-line services. The system consists of a 'set-top box' that connects the television screen to a telephone line or cable. The line or cable is connected to a central computer (server) that contains databases, a film library, or other material offered to consumers. The consumer browses through the material offered (for example films), chooses, and communicates his choice via the 'set-top box' to the server. The server transmits the required data to each consumer individually. This is expected to lead to new services. Video-ondemand will imply that the consumer orders a film from a catalogue. The film is then transmitted to the consumer whenever desired. This service provides an alternative to the existing service of video rental stores. Other services may be completely new, but any alternatives are yet unproven. Set-top boxes can be based on existing multimedia systems, which gives current suppliers an advantage over companies developing a dedicated (new) set-top box.

Collecting information from mainly U.S. business magazines, I counted 34 interactive television projects (mostly experiments). Ten of these seemed to be conducted by one firm; the others are alliances. General Instrument, Microsoft, TCI, Time Warner, and US West participated in four projects; AT\&T, Hewlett Packard, Philips, and Silicon Graphics participated in three projects. This indicates the various markets whose incumbents are interested in interactive television. These companies include telecommunication firms (AT\&T, US West), cable-TV firms (General Instrument, TCI, Time Warner), computer firms (Microsoft, Hewlett Packard, Silicon Graphics), and consumer electronics (Philips). Note a salient characteristic of alliances: these firms participate in several of them. This may lead to harmful opportunism. For example, a firm's many alliances may lead to a conflict of interest that it may resolve to the disadvantage of some of its partners. Alliances combine different kinds of firms (in terms of size and home market). This may allow for a rapid spread of know how and creative ideas.

Two alliances reported are attempts at setting an industry standard. Microsoft teamed up 
with Alcatel, Andersen Consulting, Lockheed, NTT, Olivetti, Deutsche Telekom, Telstra, and US West. Oracle organised a Set-top Alliance whose partners include Apple, General Instrument, 3DO, Goldstar, Hewlett Packard, Philips, Pioneer, Samsung and Sharp (Automatisering Gids, 17-2-95). The two organisers, Microsoft and Oracle, try to play a leading role in setting the standards (Fortune, 29-11-93, p. 25-31). The other alliances aim at pooling the participants' resources. The large number of alliances may be related to the uncertainty of each project. Users of interactive television (final consumers, as well as cable-TV companies and content suppliers), may want an industry standard to emerge. If so, the chance of any project that it succeeds is but small, and the risks high. An important impediment is that many experiments fail to keep consumers busy: there is a lack of compelling services (The Economist, 25-2-95, p. 69-70). The risks (from the supply side as well as the demand side) may explain why no fim can succeed without alliances. The next subsection looks at the related issue of multimedia content.

\subsection{The battle for content}

Multimedia can only succeed if it offers consumers genuine entertainment or information. Multimedia may be a new way to commercialise existing films, scenarios, books, data, news, etc. Many observers believe that good content will become a scarce commodity, and its intellectual property will become a major asset. This view has inspired numerous mergers and acquisitions. A striking illustration are the acquisitions of American film libraries and studios (see table $3)$.

These ventures are less risky than the interactive television projects mentioned above. The value of a film library can more readily be assessed, and the notion that its value will increase due to multimedia is relatively uncontroversial. Integrating a film studio in one's main operations is, however, more difficult. A film library is an asset, a film studio is a

people's business. Neither Table 3

Sony nor Matsushita have so

\begin{tabular}{|c|c|c|c|}
\hline Target & Acquirer & Year & $\begin{array}{l}\text { Price } \\
(\mathrm{m} . \$)\end{array}$ \\
\hline MGM Film Library & $\begin{array}{l}\text { Turner Broadcasting } \\
\text { System }\end{array}$ & 1986 & 1,400 \\
\hline Columbia Pictures & Sony & 1989 & 3,400 \\
\hline $\begin{array}{l}\text { Guber-Peters } \\
\text { Productions }\end{array}$ & Sony & 1989 & 200 \\
\hline MCA Universal & Matsushita & 1990 & 6,100 \\
\hline Propaganda films & Polygram & 1991 & \\
\hline Working Title Films & Polygram & 1991 & \\
\hline New Line & \multirow{2}{*}{$\begin{array}{l}\text { Turner Broadcasting } \\
\text { System }\end{array}$} & \multirow[t]{2}{*}{1993} & \multirow[t]{2}{*}{667} \\
\hline Castle Rock & & & \\
\hline Paramount & Viacom & 1994 & 10,000 \\
\hline Island Pictures & Polygram & 1994 & \\
\hline Republic Pictures & $\begin{array}{l}\text { Blockbuster } \\
\text { Entertainment }\end{array}$ & 1993 & 25 \\
\hline $\begin{array}{l}\text { Spelling } \\
\text { Entertainment Group }\end{array}$ & $\begin{array}{l}\text { Blockbuster } \\
\text { Entertainment }\end{array}$ & 1993 & 163 \\
\hline
\end{tabular}


far succeeded in integrating their film studios in a multimedia strategy. Sony did try to integrate Columbia Pictures, but a series of failures led to its corporate loss of $\$ 3.2$ billion in the second quarter of 1994. Matsushita tried less hard to create synergies, but its stand-offish approach was not appreciated either. MCA managers demanded to buy back control of MCA, complaining that Matsushita did not invest enough (Wall Street Journal Europe, 18-11-94). Integrating activities is a great problem in mergers.

\subsection{Sony}

Due to the newness of multimedia, there does not yet seem to be a pure multimedia firm. Some established firms, however, focus their strategies strongly on multimedia. Sony is an example. In the 1980s Sony began to anticipate the development of multimedia. With Philips it introduced the CD-ROM standard in 1986. It anticipated the need for content, as witnessing its foray into Hollywood (see table 2). The logic seemed compelling for industry observers who stress synergy (this naturally excludes The Economist), for example:

'Sony Corp. boasts a fuller cupboard of ingredients than any other company trying to cook up a digital stew.' (Business Week, 7-9-92, p. 54) "We're the best-positioned company in the world.", according to Michael P. Schulhof, vice-chaim an of Sony Corp. of America.

The acquisitions are part of a strategy by Sony to move into software, movies, music, and CDROM based video games:

This is where owning a movie studio is beginning to give Sony an edge, says Olaf Olafsson, president of Sony Electronic Publishing Co. While producing movies, he says, Sony can shoot extra footage for use in interactive video games.' (Business Week, 7-9-92, p. 54)

Recent years, however, suggest that Sony's strategy begins to falter. Its 1994 loss, reported above, is an indication. So is the difficulty it faces to get its new High Density CD format accepted by the leaders in the IT industry and Hollywood. Where did it go wrong? For one, Sony has bet on too many standards for multimedia. Its (physically or software-based) incompatible CD formats include the Mini Disc, the Electronic Book, CD-i (which it pledged support to, in 1991), and the PlayStation videogame console. In 1992 it introduced the MMCD, a portable Multimedia CD Player using a CD format similar to CD-ROM XA but unable to play most existing Multimedia PC software (PC Magazine, 22-12-1992, p. 304). That adds up to five incompatible CD standards, of which three are physically of different size. It was of course impossible to have a commitment to all of them. Betting on several standards leads to under-investment and may lead to collective failure. Sony may lack a vision that lends consistency and coordination to its activities.

Another problem is that it may not be active enough in alliances. For example, Sony is not reported among the participants of the 34 interactive television projects mentioned above. ${ }^{3}$ Its

3. A company it is related too, United Video, is mentioned once. 
PlayStation started as a cooperation with Nintendo. Since Nintendo pulled out, Sony owns the PlayStation as a proprietary system (Business Week, 23-5-94, p. 21). Cooperation is limited to writing contracts with 164 Japanese game developers. The CD format battle, mentioned above, suggests that Sony does not use its foray into Hollywood as an instrument in gaining access to Hollywood and forging alliances. Merger policies, that is, should be coordinated with a firm's alliances. Sony's example may show that even early (and presumably well-prepared) moves by a large company can go amiss.

\section{Appraisal}

The cases show that firms' preference for mergers or alliances differs from one case to the next. Developing an operating system (an architecture) is not quite the same thing as developing a CD format (a standard), or making movies or videogames (intellectual property and shared resources). Moreover, firms have different capabilities and ambitions. Aspiring multimedia empires, such as Sony and Viacom, prefer acquisitions for the sake of control and ownership. Some tentative conclusions can be stated.

Mergers in multimedia may be motivated by a strategy of combining resources into new core competencies. Scarcity and the associated value of these resources may further enhance a strategy of acquisitions. Uncertainty about the value and product life of an innovation, convergence (increasing substitutability of IT products), and the need to piece together very different resources, may instead inspire alliances. Standard setting (e.g., for an operating system, storage format, or communication protocols) is another motive for alliances. Mergers and alliances can be instruments to gain a first move. However, technological uncertainty, learning, and the continuous flow of innovations may undermine first move advantages. Alliances can serve as a low cost monitoring device to track several competing innovations simultaneously, without having to commit to only one of them. These comments indicate that mergers and alliances can be complementary. A feasible multimedia strategy may require a firm to adjust its core competencies by means of (de)mergers, while realising more risky or adjacent activities in alliances. Coordinating a firm's merger policy with its networking (alliance) policy is a difficult balancing act for management. The consistency between a firm's merger and its alliances policies is an important area for future studies, as is the consistence between them and its technology and market policies. 


\section{REFERENCES}

D'Aspremont, C. and A. Jacquemin (1988) Cooperative and Noncooperative R\&D in Duopoly with Spillovers, American Economic Review, 78(5), Dec.: 1133-1137.

Bondt, R. de, and R. Veugelers (1991) Strategic Investment with Spillovers, European Journal of Political Economy, 7: 345-366.

Davidson, C. and R. Deneckere (1984) Horizontal Mergers and Collusive Behavior, International Journal of Industrial Organization 2: 117-132.

Farrell, J. and G. Saloner (1988) Coordination through Committees and Markets, RAND Journal of Economics 19(2), Summer 1988, p. 235-252.

Ferguson, Ch. H. and Ch. R. Morris (1994) Computer Wars: the Fall of IBM and the Future of Global Technology, New York: Times Books.

Hart, O. and J. Moore (1990) Property Rights and the Nature of the Firm, Journal of Political Economy, 98(6): 1119-1158.

Jong, H.W. de (1993) Market Structures in the European Economic Community, in De Jong, H.W. (ed.) 1993, The Structure of European Industry, Dordrecht: Kluwer Academic Publishers, chapter 1, p. 1-42.

Wegberg, M. van (1994a) Multi-market Competition Theory: a Conceptual Framework, Maastricht: Datawyse.

Wegberg, M. van (1994b) The Choice between Merger and Alliance: The Implications of the Merger for Market Power Paradox, Maastricht: University of Limburg Research Memorandum RM /0/94-023.

Wegberg, M. van (1995a) Can R\&D Alliances Facilitate the Formation of a Cartel? The Example of the European IT Industry, Maastricht: University of Limburg, Research Memorandum, RM/95/006.

Wegberg, M. van (1995b) Vertical Merger versus R\&D-Alliance: Cooperation by Innovators and Manufacturing Fims, Maastricht: University of Limburg, Research Memorandum, RM. 